last year. Five were caught within one mile of where they were banded last year, and one was four miles away. It is interesting to note that none of the 357 young bluebirds banded last year were found nesting in any of the houses this year. During the past two years I have banded 1000 bluebirds.

The Tree Swallows also had a successful year despite the fact that House Sparrows occupied many of the older houses. This year there were at least 325 houses occupied by Tree Swallows, compared to 275 in 1969. A total of 850 Tree Swallows was banded this past season, bringing the two-year total to 1450 . There were 123 adult female Tree Swallows banded this year, and 19 of the 125 banded last year were re-caught on nests. Most of them were re-caught within a mile of where they were banded or at the same nest, but one was nesting 75 miles away. Again it was interesting to note that none of the young Tree Swallows banded last year were found nesting in any of the houses.

\section{SASKATOON JUNIORS' BLUEBIRD REPORT, 1970}

by Michael Bantjes and David V. Houston, Saskatoon

The Saskatoon Junior Natural History Society was formed in November 1968 , with seven members between the ages of 10 and 14. It was formed to enable the younger members of the Natural History Society to have active participation in various phases of natural history. We now have over 20 members.

Our main project over the last two years has been the construction and maintenance of a bluebird box trail. It extends from Saskatoon to Raymore with a total of 368 houses, spaced about one-third of a mile apart. The boxes were placed four feet above the ground and at least 100 yards from trees, and 200 yards from farmyards when possible.

During the breeding season we were able to check all the 182 houses within the Saskatoon area (which extends 20 miles east of Hanley) and 55 houses west of Raymore, leaving 131 intervening houses unchecked. Occupancy was as follows:

\begin{tabular}{lrr} 
& \multicolumn{3}{c}{ Saskatoon } & Raymore \\
Tree Swallow ........... & 130 & 38 \\
Mountain Bluebird .... & 8 & 0 \\
House Sparrow ......... & 11 & 6 \\
Empty all year ......... & 15 & 2 \\
Damaged or destroyed & 22 & 9 \\
Used by two species ... & -4 & $\ldots$ \\
\cline { 2 - 2 } & -.4 \\
Total ...................... & 182 & 55
\end{tabular}

We were encouraged by the Mountain Bluebird's increase from three to eight pairs, compared with 1969.

\section{A REPORT FROM ST. CHAD'S GIRLS' SCHOOL OUTINGS CLUB}

\author{
by Jane Richardson, Semans
}

The school year of 1969-70 was the second and final year of the St. Chad's Outings Club. Its life was only brought to an end because the school was forced to close. All members of the club woulu' like to thank Lorne Scott of the Museum of Natural History in Regina for his leadership and interest in the club. Thanks also goes to the Sisters for their assistance and guidance within the Outings Club.

Our activities were varied and took place at all hours. For example, last October at 5:30 in the morning, eleven of our members visited the Fred Bard Nature Refuge near Regina. Here Whistling Swans were observed resting during their long migration south. Prairie Dogs, which many of the girls had never seen before, were active in the early morning. We also visited the Interpretive Centre before returning to the city and a day of classes.

November started out with the club attending an Audubon Screen Tour film sponsored by the Regina Natural History Society and the Museum. Later in the month a field trip was taken to Lake Marguerite which is located south of Indian Head. The highlight of the trip was discovering several bison skulls and bones along the lake shore. Beaver work was also discovered in cut 


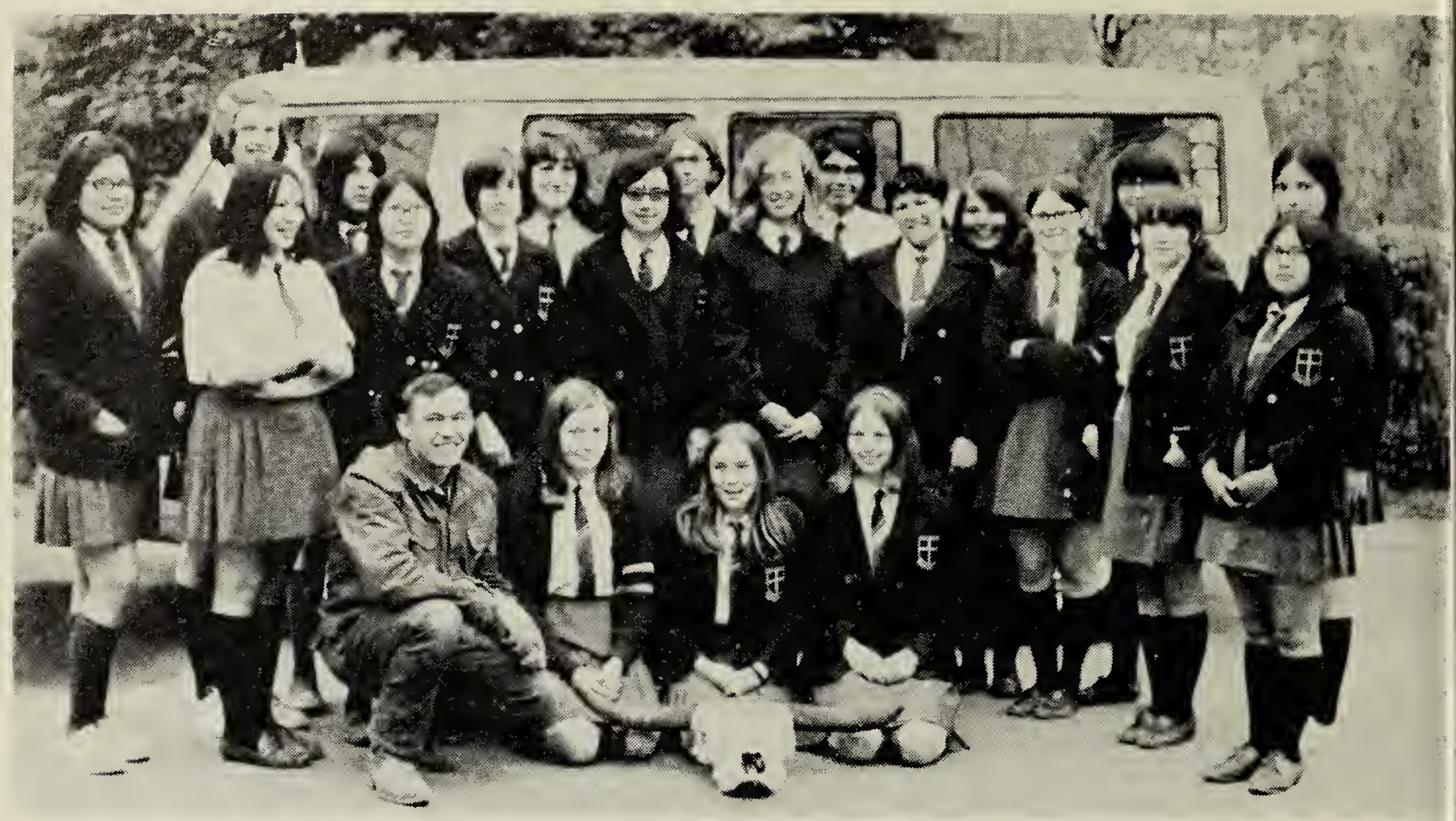

Members of the St. Chad's Outing Club, 1970

trees, canals, stockpiles of winter food and a large lodge.

During the winter months we visited the Wascana Marsh to feed the geese. Natural History meetings and Pollution Probe meetings were attended. In February some members went to Moose Jaw and two members presented a short slide talk to the local Natural History Society there. Mr. Doug Gilroy came to the school and presented an excellent slide talk on Prairie Wildlife.

The arrival of spring brought us more opportunities for outdoor activity. Bird houses were set up around the school grounds including a 28-apartment martin house. At 4:00 one morning we managed to go to the dancing grounds of the Sharp-tailed Grouse. A great many birds were around, some only a few feet away. One even managed to land on the roof of Lorne's panel truck.

Other spring trips included banding young Great Horned Owls and Mountain Bluebirds around Indian Head. The club's largest and last undertaking of the year was an overnight campout at Deep Lake, south of Indian Head. We arrived in the early evening and had the camp set up before dark. The rest of the evening was spent roasting wieners and marshmallows, and joining in a singsong. Next morning, we had an early breakfast and set out on a hike around the lake. Several species of birds were seen, as well as a coyote loping across a hillside. A rubber raft was used to get back to the campsite, and since most of the girls were wet by the time we got there, we all went in for a swim. We returned to the city tired but happy.

As all members of the St. Chad's Outings Club will agree, we learned a lot and had a lot of fun. Perhaps you can get someone in your town to start a similar club at your school.

\section{JUNIOR NATURALISTS}

Three of the reports printed in the preceding pages were given at the SNHS annual meeting in Saskatoon, October 17, 1970. It was suggested that the reports of our junior naturalists be printed in the Blue Jay and that the various organized junior naturalists consider the writing and submitting of group reports as one of their activities. Items for the 1971 March Blue Jay should reach Mrs. Joyce Deutscher, 7200 6th Avenue, Regina by January 15, 1971. 